\title{
Hemophilia care in the state of Rio de Janeiro, Brazil
}

\author{
Eva M. A. Fontes, ${ }^{1}$ Luiz Amorim, ${ }^{1}$ Silvia M. Carvalho, ${ }^{1}$ \\ and Miguel B. Farah ${ }^{2}$
}

ABSTRACT In the developing countries of the world, few people with hemophilia receive adequate care. Nevertheless, Brazil has made significant advances in the treatment of hemophilia over the last decade. The provision of factor concentrates imported by the Government of Brazil is gradually increasing, and patients receive the concentrates for free. A national register was established as well as a coordinated program for comprehensive care. Of the 6297 persons with hemophilia in Brazil who were registered as of January 2001, 689 of them (11.1\%) were registered in the state of Rio de Janeiro. Of those 689, 664 of them were being monitored at the state's coordinating blood transfusion center, which is located in the city of Rio de Janeiro. Among those 664, factor VIII inhibitors were identified in 81 of them (12.2\%). Among 653 of the Rio de Janeiro patients who were tested for transfusion-transmitted diseases, the overall prevalence found was $41.5 \%$, with the specific rates being $13.3 \%$ for human immunodeficiency virus (HIV), 2.9\% for hepatitis B virus (HBV), and $39.4 \%$ for hepatitis C virus (HCV). The state of Rio de Janeiro has adopted a comprehensive hemophilia management approach that includes medical, psychological, and social care. As a result, the quality of life of hemophilia patients has improved noticeably. For example, the rate of hospitalization among patients fell by 30\% between 1998 and 2001, and there has also been a decline in the school and work activities that they have missed.

Key words Hemophilia, health services, Brazil.

The management of hemophilia in developed countries changed dramatically in the last two decades of the 20th century, and it now focuses on replacement of absent coagulation factors produced either by plasma fractionation or through recombinant

1 Hemocentro do Rio de Janeiro (HEMORIO), Rio de Janeiro, Rio de Janeiro, Brazil. Send correspondence to: Eva Fontes, Setor de Hemostasia HEMORIO, Rua Frei Caneca, 8 - Centro, CEP 20211-030, Rio de Janeiro, RJ — Brazil; fax: 5521 25493476; e-mail: evamfontes@uol.com.br

2 Universidade Federal Fluminense, Departamento de Patologia, Niterói, Rio de Janeiro, Brazil. technology (1). The factor VIII and factor IX concentrates now available are safe, since they are subjected to several viral inactivation steps during the production process. Though this therapy is very effective, most developing countries cannot afford it due to the extremely high costs (2-3).

In this piece we will describe improvements in hemophilia care in one developing country, Brazil, with particular attention to the progress that has been made in the state of Rio de Janeiro. Brazil is a federal republic with 26 states and a federal district (the capital city of Brasília). As of December 2000, the population of the country was 170 million (4). Various groups have contributed to the current ethnic mix found in Brazil. Among the most important of these groups have been Europeans (notably the Portuguese discoverers and subsequent immigrants), African slaves, and native Indians.

Until the mid-1990s most Brazilian hemophilia patients were treated by cryoprecipitate infusion. There was a small plasma fractionation center in the city of Rio de Janeiro that pro- 
duced intermediate-purity factor VIII concentrate. Until it closed in 1996, the center supplied around $10 \%$ of Brazil's total requirements. The remaining $90 \%$ was covered by transfusions of cryoprecipitate and the administration of factor VIII concentrate imported either by state governments or by individual hospitals providing hemophilia care. Also in the mid-1990s more than $60 \%$ of the people with hemophilia were serum-positive for both human immunodeficiency virus (HIV) and hepatitis $\mathrm{C}$ virus (HCV). In response to this situation, the Ministry of Health decided to establish a coordinated national program for hemophilia.

\section{HEMOPHILIA CARE IN BRAZIL}

Identification of persons with hemophilia remains a major problem in developing countries. The limited clinical awareness that health care professionals have, along with inadequate laboratory facilities, results in a low number of registered patients when compared to the estimated prevalence (5). Among the first steps of the Brazilian program were the development of a national register of people with hemophilia and the organization and qualification of laboratory services.

Based on an incidence of about 1 in 10000 male births (6), it can be assumed that the expected prevalence among the Brazilian population is approximately 8500 persons with hemophilia. As of January 2001 the national register listed 5411 individuals with hemophilia $\mathrm{A}$ and 886 persons with hemophilia B. Thus the number of registered persons with hemophilia is smaller than the estimated number, which may be due to the unavailability of adequate laboratory tests in some parts of the country.

Brazil has a network of 33 state blood transfusion coordinating centers, all reporting to the National Health Surveillance Agency (Agência Nacional de Vigilância Sanitária, or ANVISA). The network in each state consists of three types of facilities: 1) the coordinating blood transfusion center (one per state, except for the state of
São Paulo, where there are seven coordinating centers), 2) regional blood transfusion centers (from 3 to 20 per state), and 3) transfusion services (nearly 2500 around the country). The transfusion services and the regional blood transfusion centers report to the respective state coordinating centers. In total, there are 300 facilities that collect blood and 2500 transfusion services in Brazil. Most of the services that collect blood also perform pretransfusion tests and transfuse blood components.

Twenty out of the 33 coordinating centers have laboratories equipped to perform the required tests for hemophilia care, including: 1) prothrombin time, 2) activated partial thromboplastin time (APTT), 3) factor VIII assay, 4) factor IX assay, 5) screening for inhibitors, 6) von Willebrand factor antigen (vWF:Ag), and 7) ristocetin cofactor assay (vWF:RCoF) (7). Most of the hemophilia patients have been diagnosed and treated at these coordinating blood transfusion centers. In the state of Rio de Janeiro, for example, all persons with hemophilia have been diagnosed at the coordinating blood transfusion center, which is located in the city of Rio de Janeiro. Some $96 \%$ of the people with hemophilia in the state are followed up at that center. The remaining individuals are followed up at other public or private facilities.

The features offered by facilities that treat persons with hemophilia vary among the different states. States where the health care infrastructure is most developed also have reference laboratories and a specialized organization for the management of hemophilia patients.

When the national register and the laboratory network were consolidated in the mid-1990s, Brazil's Unified Health System (Sistema Único de Saúde, or SUS) began to import factor VIII and factor IX concentrates for hemophilia treatment at a rate of 10000 units of factor VIII concentrate per hemophiliac per year. The national government also organized the distribution of the factor concentrates. In each state, the coordinating blood transfusion centers are responsible for re- ceiving, storing, and distributing the products to all their hemophilia care centers.

Hemophilia patients receive the factor concentrates free of charge, and any hemophiliac is entitled to receive the product, even those patients under private hospital care. Even unregistered patients can obtain enough factor VIII or factor IX to cover a 48-hour period while their attending physician fills out the pertinent registration forms.

The Government of Brazil has imported increasing quantities of factor VIII and factor IX concentrates. In 2001 the Ministry of Health purchased factor concentrates at a rate of 30000 units per hemophiliac per year (8). The Government has also begun importing activated and nonactivated prothrombin complex, von Willebrand-enriched factor VIII concentrates, and recombinant factor VIIa. Patients also receive these products for free.

The protocols that facilities and physicians apply in treating persons with hemophilia follow national guidelines issued by the Ministry of Health (9). These protocols are based on the recommendations of the World Federation of Hemophilia (10).

\section{HEMOPHILIA CARE IN THE STATE OF RIO DE JANEIRO}

As of the last census, in 2001, the state of Rio de Janeiro had 15 million people. There were an estimated 750 persons with hemophilia, but the actual numbers of registered individuals with hemophilia A and hemophilia B were 589 and 100, respectively (11).

All the hemophilia patients in Rio de Janeiro have been diagnosed at the Rio de Janeiro Blood Transfusion Center (RJBTC) (Hemocentro do Rio de Janeiro, or HEMORIO), which is the state coordinating blood transfusion center. Of those diagnosed patients, $96 \%$ of them are treated at the RJBTC, with the remainder being treated at other institutions.

RJBTC has a laboratory that qualifies as a "comprehensive coagulation laboratory," according to criteria of the World Federation of Hemophilia (7). 
TABLE 1. Age distribution of people with hemophilia monitored at the Rio de Janeiro Blood Transfusion Center, state of Rio de Janeiro, Brazil, 2001

\begin{tabular}{lcc}
\hline Age range (years) & No. & $\%$ \\
\hline $0-10$ & 142 & 21.4 \\
$11-20$ & 155 & 23.4 \\
$21-30$ & 115 & 17.3 \\
$31-40$ & 103 & 15.5 \\
$41-50$ & 79 & 11.9 \\
$51+$ & 70 & 10.5 \\
$\quad$ Total & 664 & 100 \\
\hline
\end{tabular}

The laboratory performs screening tests for bleeding disorders, correction studies, factor assays (VIII, IX, I, II, V, VII, X, XI), inhibitor assays, platelet function tests, von Willebrand factor antigen determination, and ristocetin cofactor assay.

The RJBTC monitors a total of 664 persons with hemophilia. Their age distribution is shown in Table 1, and their type of hemophilia and its severity is shown in Table 2.

A multidisciplinary approach, with the involvement of a variety of health care professionals, ensures that the medical, social, educational, and psychological needs of persons with hemophilia are met. At the time of diagnosis, hemophilia patients are seen by a specialized physician for the first clinical evaluation. The attending physician sends the patient to a nurse who talks about the disease and provides information on such procedures as receiving and using products, making appointments with physicians, and coming to the emergency room. The nurse also refers the patient to a dentist, a psychologist, a social assistant, and a physiotherapist.

Each patient is then scheduled for clinical and laboratory follow-up at least twice a year. During this followup, patients are also taught about home care and self-infusion, and they are referred to other specialists as needed.

The level of patients' compliance with this comprehensive management is around $90 \%$. The RJBTC has an emergency room (ER) open 24 hours per day and dedicated solely to pa- tients with blood disorders, including hemophilia. If persons with hemophilia have medical problems, they are advised to go to this ER for evaluation and treatment.

Cryoprecipitate has not been used in the last 6 years in the state of Rio de Janeiro. The treatment of hemorrhagic episodes consists of the administration of high-purity factor VIII or IX concentrates. Since February 2002 a national law has banned the use of cryoprecipitate or fresh frozen plasma for treating hemorrhages in persons with hemophilia because of the ready availability of industrial concentrates throughout the country. The Ministry of Health only buys and dispenses plasma derivatives, except for a small amount of recombinant factor VII, which is used for treating some patients with factor VIII inhibitor.

Primary prophylaxis (factor VII or factor IX replacement done two or three times per week on a regular basis) is not practiced in Brazil, due to its high costs. Secondary prophylaxis (the prophylactic use of factor VIII or IX concentrates for persons with hemophilia at a high risk of bruising) is sometimes performed to prevent recurrent bleeding into target joints.

A program for home infusion of factor concentrates for selected patients began two years ago in Rio de Janeiro. These patients receive special training in identifying early symptoms of hemorrhage and in factor infusion. The patients take the early treatment at home, and on the following day they visit the hemophilia service to be evaluated and to replace the emergency home dose (8).

Among the 653 persons with hemophilia in the state of Rio de Janeiro who have been tested, the overall prevalence of transfusion-transmitted diseases is $41.5 \%$. The specific rates for HIV, hepatitis B virus (HBV), and $\mathrm{HCV}$ are $13.3 \%, 2.9 \%$, and $39.4 \%$, respectively (Table 3). Among the HIV-

TABLE 2. Distribution of hemophiliacs, by severity and type of hemophilia, monitored at the Rio de Janeiro Blood Transfusion Center, state of Rio de Janeiro, Brazil, 2001

\begin{tabular}{lrrrrr}
\hline & \multicolumn{3}{c}{ Type } \\
\cline { 2 - 3 } \cline { 5 - 6 } Severity & \multicolumn{2}{c}{ Hemophilia A } & & \multicolumn{2}{c}{ Hemophilia B } \\
\cline { 2 - 3 } \cline { 5 - 6 } & No. & $\%$ & & No. & $\%$ \\
\hline Severe & 349 & 61 & & 49 & 53 \\
Moderate & 86 & 15 & & 11 & 12 \\
Mild & 137 & 24 & & 32 & 35 \\
$\quad$ Total & 572 & 100 & & 92 & 100 \\
\hline
\end{tabular}

TABLE 3. Prevalence of viral infections among people with hemophilia monitored at the Rio de Janeiro Blood Transfusion Center, state of Rio de Janeiro, Brazil, 2001 ${ }^{\text {a }}$

\begin{tabular}{|c|c|c|c|c|}
\hline \multirow[b]{3}{*}{ Virus $^{b}$} & \multicolumn{4}{|c|}{ Serological test result } \\
\hline & \multicolumn{2}{|c|}{ Positive } & \multicolumn{2}{|c|}{ Negative } \\
\hline & No. & $\%$ & No. & $\%$ \\
\hline HIV & 87 & 13.3 & 566 & 86.7 \\
\hline HBV & 19 & 2.9 & 634 & 97.1 \\
\hline $\mathrm{HCV}$ & 257 & 39.4 & 396 & 60.6 \\
\hline
\end{tabular}


TABLE 4. Prevalence of inhibitors among 664 people with hemophilia monitored at the Rio de Janeiro Blood Transfusion Center, state of Rio de Janeiro, Brazil, 2001

\begin{tabular}{lcrr}
\hline & & \multicolumn{2}{c}{ Inhibitor } \\
\cline { 3 - 4 } Hemophilia type & No. of patients & No. & \multicolumn{1}{c}{$\%$} \\
\hline Hemophilia A & 572 & 80 & 14.0 \\
Hemophilia B & 92 & 1 & 1.1 \\
Total/Overall & 664 & 81 & 12.2 \\
\hline
\end{tabular}

TABLE 5. Classification of inhibitors among 81 patients with hemophilia monitored at the Rio de Janeiro Blood Transfusion Center, state of Rio de Janeiro, Brazil, 2001

\begin{tabular}{|c|c|c|c|c|c|c|c|}
\hline \multirow[b]{2}{*}{ Hemophilia type } & \multirow{2}{*}{$\begin{array}{l}\text { No. of } \\
\text { patients with } \\
\text { inhibitor }\end{array}$} & \multicolumn{2}{|c|}{$\begin{array}{c}\text { High } \\
\text { responders }\end{array}$} & \multicolumn{2}{|c|}{$\begin{array}{l}\text { Low } \\
\text { responders }\end{array}$} & \multicolumn{2}{|c|}{$\begin{array}{l}\text { Transient } \\
\text { inhibitor }\end{array}$} \\
\hline & & No. & $\%$ & No. & $\%$ & No. & $\%$ \\
\hline Hemophilia A & 80 & 27 & 34 & 28 & 35 & 25 & 31 \\
\hline Hemophilia B & 1 & 1 & 100 & 0 & 0 & 0 & 0 \\
\hline
\end{tabular}

positive patients, $86.4 \%$ are also seropositive for $\mathrm{HCV}$.

The RJBTC has identified inhibitors in 81 hemophilia patients, or roughly $12 \%$ of the 664 whom it monitors. The prevalence among the patients is shown in Table 4, and Table 5 classifies the inhibitors.

Hemorrhagic episodes in patients with inhibitors are primarily treated by infusion of prothrombin complex or activated prothrombin complex. In severe cases, if there is no response to this treatment, recombinant factor VIIa is used. There are no patients in immune tolerance induction programs in Brazil. These programs use a very large amount of factor VIII concentrates in patients with inhibitor, in order to modulate the immune response and to suppress inhibitor production. Such a program is still not affordable for Brazil since it would significantly increase the country's demand for these products.

The costs of managing hemophilia in Brazil, including supplying factor VIII and factor IX concentrates and activated prothrombin complex, are fully covered by Brazil's Unified Health System. The purchase of concentrates by the Ministry of Health amounts to some US\$ 70 million annually, or a mean cost of about US $\$ 11100$ per person with hemophilia per year (12).
Improvements in the quality of life of persons with hemophilia in Rio de Janeiro are estimated through such indicators as a decrease in the rate of absenteeism at school and at work, a decreased number of hospital days, a lower rate of long-term joint complications, and the patients' rate of return to regular life activities. As a result of the comprehensive management, the rate of hospitalization in Rio de Janeiro fell 30\% between 1998 and 2001, and the patients' return to regular activities improved significantly, since they were less prone to missing school and work.

\section{CONCLUSIONS}

The comprehensive management of hemophilia is feasible even in developing countries, provided there is safe and effective therapy for these patients.

The approach adopted in the state of Rio de Janeiro has proved to be successful, both in terms of diagnostic accuracy and of coverage with the proper therapy, and it has significantly improved the quality of life of the affected persons.

The next target for Brazil's Unified Health System is the pursuit of self-sufficiency in factor VIII and factor IX, that is, supplying factor VIII and factor IX obtained exclusively from the plasma of Brazilian donors. The ultimate goal is to maximize the cost-effectiveness of this therapy and to see that the System applies state-of-the-art standards in managing hemophilia. 


\section{REFERENCES}

1. Bird A, Isarangkura $P$, Almagro D, Gonzaga A, Srivastava A. Factor concentrates for haemophilia in the developing world. Haemophilia 1998;4:481-485.

2. Aledort LM. Unsolved problems in haemophilia. Haemophilia 1998;4:341345.

3. Srivastava A. Delivery of haemophilia care in the developing world. Haemophilia 1998;4(Suppl. 2):33-40.

4. Brasil, Instituto Brasileiro de Geografia e Estatística. Censo 2000. Available from: http://www.ibge.gov.br/ibgteen/mapas/ imagens/brasil_regioes.html [Internet site]. Accessed 29 May 2002.

5. Srivastava A, Chuansumrit A, Chandy M, Duraiswamy G, Karagus C. Management of haemophilia in the developing world. Haemophilia 1998;4:470-480.
6. Miller $\mathrm{CH}$. Genetics of hemophilia and von Willebrand's disease. In: Hilgartner MW, Pochedly C, eds. Hemophilia in the child and adult. New York: Raven Press; 1989. Pp. 297-345.

7. Peake I, Seligsohn U, Gitel S, Kitchen S, Zivelin A. The laboratory diagnosis of haemophilia: recommendations of the Laboratory Activities Committee of the World Federation of Hemophilia. Haemophilia 1995;3:159-164.

8. Antunes SV. Haemophilia in the developing world. Haemophilia 2002;8:199_ 204.

9. Brasil, Ministério da Saúde, Secretaria de Assistência à Saúde, Departamento de Assistência e Promoção à Saúde, Coordenação de Sangue e Hemoderivados. Normas técnicas para o tratamento da hemofilia. Brasília: Ministério da Saúde; 1994.
10. World Federation of Hemophilia. Protocols for the treatment of hemophilia and von Willebrand Disease. WFH Bulletin 1998;14:1-20.

11. Brasil, Agência Nacional de Vigilância Sanitária, Gerência Geral de Sangue e Hemoderivados. Relatório estatístico de 2001 coagulopatias hereditárias/pacientes cadastrados. Brasília: ANVISA; 2002.

12. Brasil, Agência Nacional de Vigilância Sanitária. Programa de hemoderivados. Available from: http://www.anvisa.gov. br/sangue/apresenta_hemoderivados. pps [Internet site]. Accessed 10 July 2002.

Manuscript received 26 March 2002. Revised version accepted for publication on 19 November 2002.

RESUMEN En los países en desarrollo, pocas personas con hemofilia reciben un tratamiento adecuado. No obstante, el Brasil ha logrado grandes avances en este sentido en el último decenio. La provisión de concentrados de factores de la coagulación importados por el gobierno de Brasil va aumentando gradualmente y los pacientes reciben el concentrado gratis. Un registro nacional se estableció junto con un programa coordinado de atención global. De las 6297 personas con hemofilia en el Brasil que estaban inscritas en enero de 2001, 689 de ellas (11,1\%) estaban inscritas en el estado de Rio de Janeiro. De esas 689, 664 estaban bajo el control del centro coordinador de transfusiones sanguíneas del estado, que se ubica en la ciudad de Rio de Janeiro. De esas 664 personas, $81(12,2 \%)$ mostraron la presencia de inhibidores del factor VIII. Entre los 653 pacientes en Rio de Janeiro que fueron sometidos a pruebas para el tamizaje de enfermedades transmitidas por transfusión, se encontró una prevalencia general de 41,5\%, con tasas específicas de 13,3\% en el caso del virus de la inmunodeficiencia humana (VIH), de 2,9\% en el del virus de la hepatitis B (VHB) y de 39,4\% en el del virus de la hepatitis C (VHC). El estado de Rio de Janeiro ha adoptado un programa para el tratamiento global de la hemofilia que abarca atención médica, psicológica y social. Como resultado, la calidad de la vida de los pacientes con hemofilia ha mejorado notablemente. Por ejemplo, la tasa de ingresos en estos pacientes bajó 30\% entre 1998 y 2001, y también se ha observado un descenso de las actividades escolares y laborales perdidas a causa de la enfermedad. 